\title{
PERANCANGAN STRATEGI PENINGKATAN KUALITAS PELAYANAN DENGAN METODE SERVQUAL DI TOSERBA MANDIRI DEMANGSARI
}

\author{
Tofik Nurhidayat, Widyastuti \\ Program Studi Teknik Industri \\ Sekolah Tinggi Teknologi Muhammadiyah Kebumen \\ tofiknurhidayat94@gmail.com,widyas2tix@gmail.com
}

\begin{abstract}
Abstrak
Toserba Mandiri Demangsari merupakan salah satu mini market yang berada di, Kabupaten Kebumen dengan tingkat kunjungan mencapai 18.000 orang pertahun. Persaingan dalam bidang retail yang semakin ketat menuntut Toserba Mandiri Demangsari untuk meningkatkan kualitas pelayanannya. Berdasarkan hal tersebut dalam penelitian ini dilakukan perancangan strategi peningkatan kualitas pelayanan dengan metode servqual di Toserba Mandiri Demangsari. Penelitian diawali dengan identifikasi permasalahan service quality yang berdasarkan lima (5) dimensi yaitu tangible, reliability, responsiveness, assurance, dan empathy. Langkah selanjutnya ialah menentukan kriteria-kriteria dalam setiap dimensi dengan menggunakan metode FGD. Pembobotan prioritas kriteria yang ada di dalam setiap dimensi dilakukan dengan metode AHP. Dari hasil metode AHP ini diperoleh rekomendasi prioritas perbaikan kualitas pelayanan yaitu Toserba perlu melengkapi fasilitas-fasilitasnya (64\%), Toserba perlu menyediakan tempat parkir yang nyaman (55\%), Toserba perlu memberikan informasi produk yang jelas pada setiap barang yang dijual (25\%), Toserba perlu melengkapi barang-barang belanjaan (20\%), Toserba perlu meningkatkan keterampilan kasir untuk dapat bekerja dengan cepat dan akurat (12\%), Toserba perlu meningkatkan kemampuan karyawan untuk cepat tanggap terhadap keluhan konsumen (11\%), Toserba perlu memberikan garansi terhadap produk barang yang cacat (8\%) dan Toserba perlu meningkatkan keramahan karyawan dalam melayani konsumen (5\%).
\end{abstract}

Kata kunci: Servqual, Service Quality, FGD, AHP, Toserba

\section{PENDAHULUAN}

Toserba Mandiri Demangsari merupakan salah satu mini market yang berada di Desa Demangsari, Kecamatan Ayah, Kabupaten Kebumen. Letaknya yang strategis yaitu berada di jalur pariwisata pantai Ayah membuat mini market ini ramai akan pelanggan dengan tingkat kunjungan mencapai 18.000 orang per tahun atau 1.500 orang per bulan [1]. Namun demikian mengingat persaingan retail yang semakin ketat maka diperlukan strategi peningkatan kualitas pelayanan.

Salah satu metode untuk meningkatkan kualitas pelayanan adalah service quality [2]. Metode ini menilai kualitas berdasarkan faktor tangible (bukti langsung), reliability (kehandalan), responsiveness (daya tanggap), assurance (jaminan) dan empathy (perhatian) [3]. Dengan demikian dalam penelitian ini mempunyai tujuan untuk merancang strategi peningkatan kualitas pelayanan dengan metode servqual di Toserba Mandiri Demangsari.

\section{LANDASAN TEORI}

\section{A. Kajian Pustaka}

Aplikasi metode servqual (service quality) telah banyak diterapan diberbagai bidang antara lain di bidang perbankan dimana kualitas pelayanan sangat mempengaruhi kepuasan dan loyalitas nasabah. Kualitas pelayan tersebut secara signifikan dipengaruhi oleh reliability, empathy, assurance dan responsiveness [4]. Selain itu kualitas pelayanan juga diterapkan untuk mengetahui tingkat kepuasan nasabah di PT. Pegadaian [5].

Di bidang pelayanan kesehatan service quality dapat diterapkan pada analisis strategi peningkatan mutu pelayanan instalasi farmasi rumah sakit (IFRS) dengan menggunakan metode service quality dan analisis SWOT. Hasil analisis menunjukkan adanya 5 gap ketidakpuasan terhadap pelayanan di IFRS dan dari kelima gap tersebut yang paling besar adalah empathy [6], selanjutnya penelitian ini diterapkan di bidang perhotelan dimana kualitas pelayanan juga berpengaruh terhadap kepuasan pelanggan di hotel Grand Puri Manado [7]. Selain itu, service 
quality dapat diterapkan di bidang pendidikan yaitu perencanaan strategis sistem informasi smart campus untuk meningkatkan pelayanan di Politeknik Indonusa Surakarta. Penelitian ini menghasilkan 24 kriteria prioritas sistem informasi yaitu 14 sistem informasi yang sangat diprioritaskan dan 10 sistem informasi yang tidak diprioritaskan [8].

Kualitas pelayanan sangat berpengaruh di bidang jasa, diantaranya pada D\&I skin centre Denpasar, dimana kepuasan pelanggan menjadi prioritas utama untuk membentuk loyalitas pelanggan [9]. Di bidang telekomunikasi kualitas pelayanan, kualitas produk dan harga sangat berpengaruh terhadap loyalitas pelanggan kartu as telkomsel di Kota Manado [10]. Di bidang retail dan distribusi service quality digunakan untuk mengidentifikasi pengaruh kualitas layanan terhadap kepuasan pelanggan dalam membentuk loyalitas pelanggan toko Mawadah Ratu. Berdasarkan penelitian tersebut kelima dimensi pembentuk kualitas layanan terbukti berpengaruh secara signifikan terhadap kualitas layanan [11]. Dalam usaha pertokoan penelitian tentang analisis perencanaan strategi peningkatan kualitas pelayanan konsumen dilakukan dengan metode quality function deployment $(Q F D)$. Hasil analisis menunjukan bahwa perencanaan strategi peningkatan kualitas pelayanan konsumen yang dapat dilakukan dengan membuat jadwal kerja yang jelas untuk karyawan dalam menjaga outlet [12]. Pada usaha perbengkelan kualitas peyanan menjadi salah satu faktor penting dalam perencanaan strategi pemasaran usaha bengkel baru, hasil dari penelitian ini berupa konsep STPD (segmentation, targeting, positioning dan differentiation) yang diperlukan oleh inti motor Ponorogo untuk menguasai pemasaran [13].

\section{B. DASAR TEORI}

\section{Metode Service Quality}

Metode servqual (Service quality) adalah keseluruhan sifat-sifat atau karakter-karakter dari suatu pelayanan/jasa yang dibangun atas kemampuan pelayanan/jasa tersebut. [14]. Para peneliti pemasaran mengidentifikasikan lima dimensi prinsip yang digunakan pelanggan untuk menilai kualitas pelayanan yaitu : tangible (bukti langsung), reliability (kehandalan), responsiveness (daya tanggap), assurance (jaminan) dan empathy (perhatian) [15].

Service Quality Gap Model digunakan untuk mengidentifiksi kesenjangan antara persepsi pelanggan dan fakta pelayanan yang diterima oleh pelanggan. Hasil identifikasi tersebut selanjutnya digunakan sebagai dasar perbaikan kualitas pelayanan. Dengan langkah-langkah sebagai berikut : Gap 1(Customer Expectation - Management Perceptions), Gap 2 (Management Perceptions - Service Standards), Gap 3 (Service Standards - Service Delivery), Gap 4 (Service Delivery - Customer Perception) dan Gap 5 (Customer Perception - Customer Expectation), seperti yang tertera dalam gambar 1 [16].

\section{Metode $A H P$}

Metode AHP merupakan suatu model pendukung keputusan yang akan menguraikan masalah multi faktor atau multi kriteria yang kompleks menjadi suatu susunan hirarki. Dalam penelitian ini perbandingan berpasangan dilakukan pada setiap kriteria dengan membandingkan kriteria satu dengan yang lainnya. Setelah perhitungan perbandingan berpasangan setiap kriteria telah selesai maka dapat diperoleh skala prioritas untuk masing-masing kriteria. Adapun tahapan perhitungan dalam metode $A H P$ adalah mendefinisikan masalah dan menentukan solusi yang diinginkan, membuat struktur hirarki, membentuk matriks perbandingan berpasangan, menormalkan data, mengulangi langkah 3, 4, dan 5 untuk seluruh tingkat hirarki, menghitung eigen vector dan menguji konsistensi hirarki [17]. 


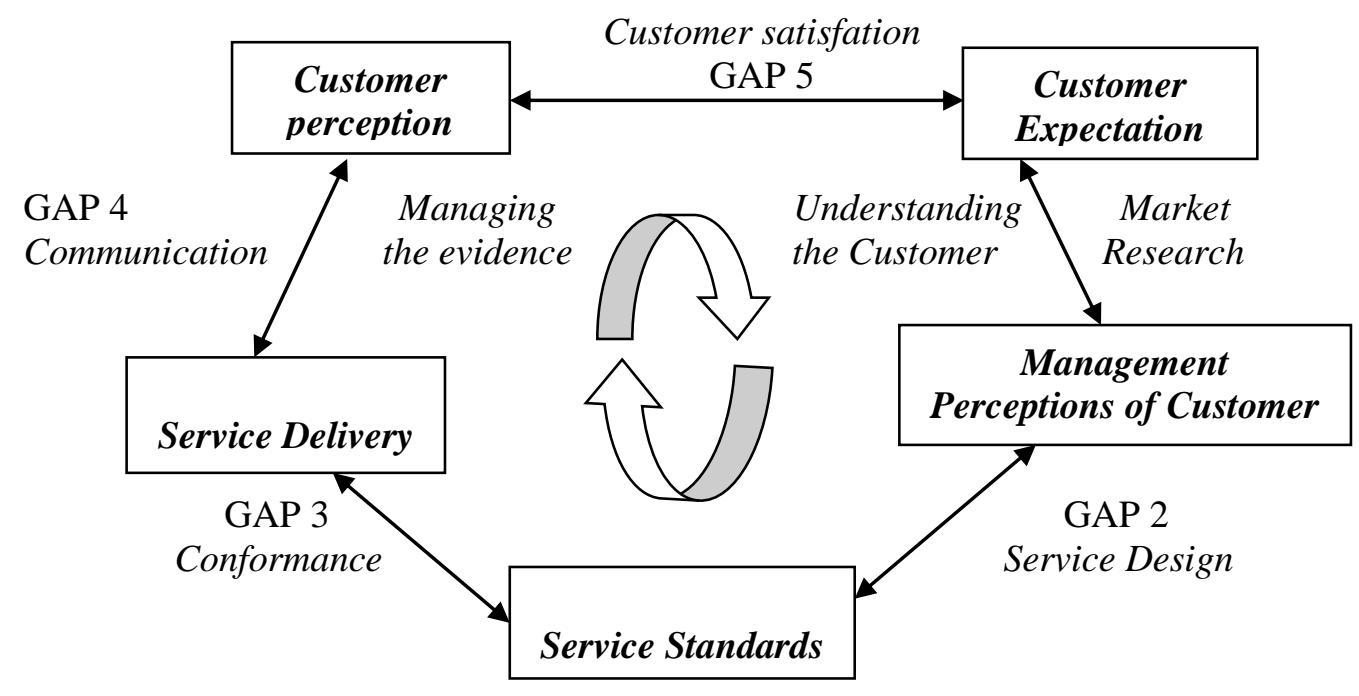

Gambar 1. Service Quality Gap Model [16]

\section{METODE PENELITIAN}

Penelitian dilakukan di Toserba Mandiri Demangsari Kabupaten Kebumen dengan tahapan penelitian sebagai berikut :

1. Identifikasi service quality di Toserba Mandiri Demangsari

Tahapan awal yang dilakukan adalah melakukan identifikasi service quality di Toserba Mandiri Demangsari, yang bertujuan untuk mengidentifikasi kesenjangan service quality yang ada. Identifikasi dilakukan menggunakan kuesioner dengan jumlah responden 94 orang yang pernah berkunjung ke Toserba tersebut. Kuesioner berisikan ke lima dimensi kualitas pelayanan yang meliputi : tangible (bukti langsung), reliability (kehandalan), responsiveness (daya tanggap), assurance (jaminan) dan empathy (perhatian). Selanjutnya dari masing-masing dimensi dilakukan uji validitas (korelasi Spearman), reliabilitas (alpha cronbach) dan analisis deskriptif yang berdasarkan kepada presentase frekuensi.

2. Penentuan kriteria dalam setiap dimensi kualitas pelayanan

Berdasarkan hasil identifikasi dilakukan penentuan kriteria kualitas pelayanan yang akan ditingkatkan. Tahap ini menggunakan metode $F G D$ yang dilakukan oleh satu kepala toko dan empat karyawan ToserbaMandiri Demangsari.

3. Penentuan prioritas strategi peningkatan pelayanan

Penentuan prioritas strategi peningkatan pelayanan dilakukan menggunakan metode $A H P$ dengan lima responden yaitu satu kepala toko dan empat karyawan Toserba Mandiri Demangsari. Penilaian dilakukan berdasarkan hasil perbandingan berpasangan antar kriteria dengan skala penilaian $1-9$ sebagaimana dijelaskan pada tabel 1 .

Setelah diperoleh hasil dari kuesioner $A H P$ selanjutnya ialah menghitung uji konsistensi indeks dan rasio dengan menentukan nilai eigen maksimum atau CI dengan rumus :

$$
\mathrm{CI}=\frac{(\lambda \mathrm{maks}-n)}{(n-1)}
$$

Jika nilai CI sama dengan nol, maka matriks pairwise comparison tersebut konsisten. Batas inconsistency ditentukan dengan menggunakan Rasio Konsistensi (CR), yaitu perbandingan indeks konsistensi dengan nilai random indeks (RI). Rasio Konsistensi dapat dirumuskan sebagai berikut :

$$
\mathrm{CR}=\frac{(\mathrm{CI})}{(\mathrm{RI})}
$$


Tabel 1. Skala Penilaian [17]

\begin{tabular}{ccl}
\hline $\begin{array}{c}\text { Itensitas } \\
\text { kepentingan }\end{array}$ & \multicolumn{1}{c}{ Definisi } & \multicolumn{1}{c}{ Keterangan } \\
\hline 1 & Sama Penting & $\begin{array}{l}\text { Kedua elemen mempunyai pengaruh } \\
\text { yang sama. }\end{array}$ \\
3 & Sedikit Lebih Penting & $\begin{array}{l}\text { Pengalaman dan penilaian sedikit } \\
\text { memihak satu elemen dibandingkan } \\
\text { pasangannya. }\end{array}$ \\
5 & Lebih Penting & $\begin{array}{l}\text { Pengalaman dan penilaian dengan kuat } \\
\text { memihak satu elemen dibandingkan } \\
\text { pasangannya. }\end{array}$ \\
7 & Sangat lebih Penting & $\begin{array}{l}\text { Suatu elemen sangat disukai dan secara } \\
\text { praktis dominasinya terlihat. } \\
\text { Satu elemen terbukti mutlak lebih } \\
\text { disukai dibandingkan dengan } \\
\text { pasangannya. }\end{array}$ \\
Ketika diperlukan sebuah kompromi
\end{tabular}

Tabel 2. Nilai Indeks Random [17]

\begin{tabular}{ccccccccccc}
\hline $\mathrm{N}$ & 1 & 2 & 3 & 4 & 5 & 6 & 7 & 8 & 9 & 10 \\
\hline $\mathrm{RI}$ & 0 & 0 & 0,58 & 0,9 & 1,12 & 1,24 & 1,32 & 1,41 & 1,45 & 1,49 \\
\hline
\end{tabular}

\section{HASIL DAN PEMBAHASAN}

\section{A. Hasil Identifikasi Service Quality Di Toserba Mandiri Demangsari}

Berdasarkan identifikasi service quality di Toserba Mandiri demangsari diperoleh hasil seperti pada tabel 3 .

Tabel 3. Hasil Identifikasi Service Quality

\begin{tabular}{cccl}
\hline No & Kriteria & & \multicolumn{1}{c}{ Sub Kriteria } \\
\hline 1 & Tangible & a) & $\begin{array}{l}\text { Toserba belum menyediakan tempat parkir yang } \\
\text { nyaman } \\
\text { Toserba belum melengkapi fasilitasnya }\end{array}$ \\
\hline 2 & beliability & a) & $\begin{array}{l}\text { Toserba belum melengkapi Barang-barang belanjaan } \\
\text { Toserba belum memberikan informasi produk yang jelas } \\
\text { pada setiap barang yang dijual }\end{array}$ \\
\hline 3 & Responsiveness & a) & $\begin{array}{l}\text { Toserba belum meningkatkan keterampilan kasir untuk } \\
\text { dapat bekerja dengan cepat dan akurat } \\
\text { Toserba belum meningkatkan kemampuan karyawan } \\
\text { untuk cepat tanggap terhadap keluhan konsumen. }\end{array}$ \\
\hline 4 & Assurance & a) & $\begin{array}{l}\text { Toserba belum memberikan garansi terhadap produk } \\
\text { barang yang cacat }\end{array}$ \\
\hline 5 & Empathy & a) & $\begin{array}{l}\text { Toserba belum meningkatkan keramahan karyawan } \\
\text { dalam melayani konsumen }\end{array}$ \\
\hline
\end{tabular}

\section{B. Penentuan Kriteria Dalam Setiap Dimensi Kualitas Pelayanan}

Berdasarkan hasil $F G D$ untuk penentuan kriteria dalam setiap dimensi kualitas pelayanan diperoleh hasil yang dapat dilihat pada tabel 4 . 
Tabel 4. Hasil Focus Group Discussion (FGD)

\begin{tabular}{|c|c|c|}
\hline No & Kriteria & Sub Kriteria \\
\hline 1 & Tangible & $\begin{array}{l}\text { a) Toserba menyediakan tempat parkir yang nyaman } \\
\text { b) Toserba melengkapi fasilitasnya }\end{array}$ \\
\hline 2 & Reliability & $\begin{array}{l}\text { a) Toserba melengkapi Barang-barang belanjaan } \\
\text { b) Memberikan informasi produk yang jelas pada setiap } \\
\text { barang yang dijual }\end{array}$ \\
\hline 3 & Responsiveness & $\begin{array}{l}\text { a) Meningkatkan keterampilan kasir untuk dapat bekerja } \\
\text { dengan cepat dan akurat } \\
\text { b) Meningkatkan kemampuan karyawan untuk cepat } \\
\text { tanggap terhadap keluhan konsumen. }\end{array}$ \\
\hline 4 & Assurance & $\begin{array}{l}\text { a) Toserba memberikan garansi terhadap produk barang } \\
\text { yang cacat }\end{array}$ \\
\hline 5 & Empathy & $\begin{array}{l}\text { a) Meningkatkan keramahan karyawan dalam melayani } \\
\text { konsumen }\end{array}$ \\
\hline
\end{tabular}

\section{Penentuan Prioritas Strategi Peningkatan Pelayanan}

Berdasarkan hasil analisis metode $A H P$ maka diperoleh prioritas dan susunan hirarki strategi peningkatan pelayan seperti yang tertera dalam gambar 2 .

\section{Pembahasan}

Berdasarkan hasil kuesioner yang telah valid dan reliabel dilakukan analisis deskriptif untuk menentukan variabel mana yang akan digunakan dalam proses $F G D$ dengan berpedoman pada nilai terendah dari setiap kriteria. Dari setiap dimensi service quality, Toserba Mandiri Demangsari masih memiliki kekurangan seperti tertera pada tabel 2. Berdasarkan data tersebut maka dilakukan $F G D$ dan diperoleh hasil kriteria perbaikan yang akan digunakan dalam peningkatan kualitas pelayanan, seperti pada tabel 3. Pentuan prioritas strategi peningkatan pelayanan dilakukan dengan metode $A H P$. Dari hasil tersebut diperoleh susunan hirarki pada gambar 2. Adapun urutan prioritas rekomendasinya adalah Toserba melengkapi fasilitasfasilitasnya, Toserba perlu menyediakan tempat parkir yang nyaman, Toserba perlu memberikan informasi produk yang jelas pada setiap barang yang dijual, Toserba perlu melengkapi barang-barang belanjaannya, Toserba perlu meningkatkan keterampilan kasir untuk dapat bekerja dengan cepat dan akurat, Toserba perlu meningkatkan kemampuan karyawan untuk cepat tanggap terhadap keluhan konsumen, Toserba perlu memberikan garansi terhadap produk barang yang cacat dan Toserba perlu meningkatkan keramahan karyawan dalam melayani konsumen. 


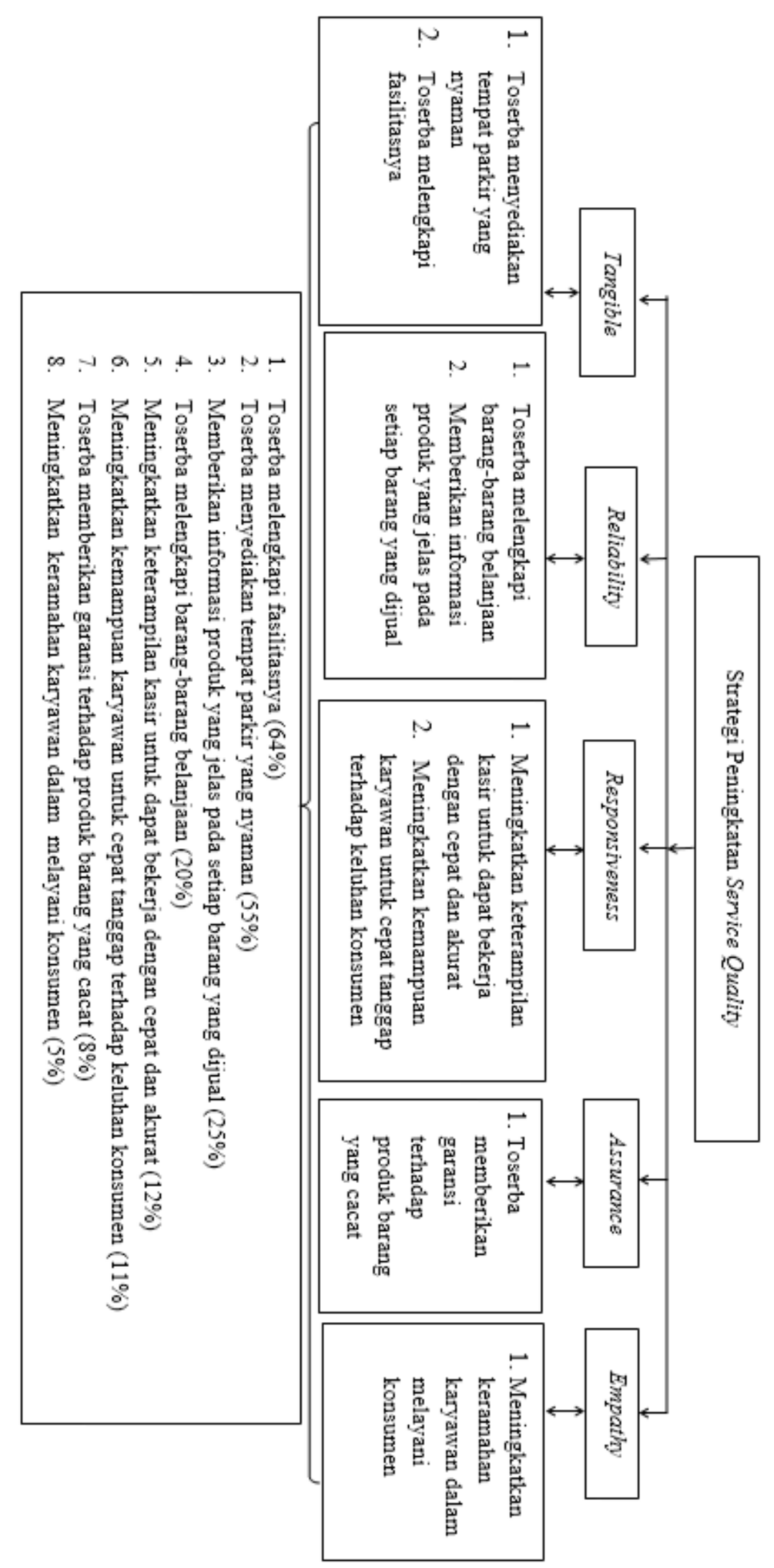

Gambar 2. Susunan Hirarki Strategi Peningkatan SERVQUAL 


\section{KESIMPULAN DAN SARAN}

\section{A. Kesimpulan}

Kesimpulan dalam penelitian ini adalah :

1. Service quality yang ada di Toserba Mandiri Demangsari saat ini masih membutuhkan perbaikan-perbaikan disemua dimensi.

2. Berdasarkan hasil analisis data yang telah dilakukan dengan metode $A H P$ maka strategi peningkatan service quality di Toserba Mandiri Demangsari sebagai berikut :

a. Toserba melengkapi fasilitas-fasilitasnya (64\%).

b. Toserba menyediakan tempat parkir yang nyaman (55\%).

c. Memberikan informasi produk yang jelas pada setiap barang yang dijual $(25 \%)$.

d. Toserba melengkapi barang-barang belanjaan (20\%).

e. Meningkatkan keterampilan kasir untuk dapat bekerja dengan cepat dan akurat $(12 \%)$.

f. Meningkatkan kemampuan karyawan untuk cepat tanggap terhadap keluhan konsumen $(11 \%)$.

g. Toserba memberikan garansi terhadap produk barang yang cacat (8\%).

h. Meningkatkan keramahan karyawan dalam melayani konsumen (5\%).

\section{B. Saran}

Saran dalam penelitian ini adalah :

Bagi para peneliti selanjutnya disarankan untuk melanjutkan penelitian ini dengan mengujikan strategi service quality di Toserba Mandiri Demangsari. Karena pada penelitian ini hasil dari analisa hanya sebagai bahan masukan bagi pihak Toserba Mandiri Demangsari kaitannya dengan meningkatkan service quality yang telah ada saat ini.

\section{DAFTAR PUSTAKA}

[1] Riyanto, Daviek interview. 2016."wawancara jumlah pelanggan Toserba". Jl. Pantai Logending.

[2] Wijaya, T. 2011. Manajemen Kualitas Jasa. PT Indeks Kembangan, Jakarta.

[3] Fitzsimmons, J. A. \& Fitzsimmons, M. J. 2011, Service Management Operations, Strategy, Information Technology, Mc Graw - Hill, London.

[4] Sudjarwo, R., \& Arifin, Z. 2014. Pengaruh Kualitas Pelayanan Terhadap Kepuasan Nasabah dan Loyalitas Nasabah. Jurnal JAB, Vol. 24, No. 1, p 1-8.

[5] Umboh, V. J., \& Mandey, S. 2014. Analisis Kualitas Jasa Layanan Pengaruhnya terhadap Kepuasan Nasabah. Jurnal EMBA, Vol. 2, No. 3, pp 654-663.

[6] Widyaningrum, n., Sampurno, \& Joko. 2013. Analisis Strategi Peningkatan Mutu Pelayanan Instalasi Farmasi Rumah Sakit. Jurnal Manajemen dan Pelayanan Farmasi, Vol. 3, No. 2, pp 144-152.

[7] Manoppo, F. 2013. Kualitas Pelayanan, dan Servicescape Pengaruhnya terhadap Kepuasan Konsumen pada Hotel Gran Puri Manado. Jurnal EMBA, Vol. 1, pp 1341-1348.

[8] Susena, E., \& Utami, E. 2015. Perencanaan Strategis Sistem Informasi Smart Campus untuk Meningkatkan Pelayanan di Politeknik Indonusa Surakarta. Jurnal Sainstech Politeknik Indonusa Surakarta, Vol. 1, No. 3, p 1-17.

[9] Putri, K. I., \& Nurcaya, I. N. 2011. Pengaruh Dimensi Kualitas Pelayanan Jasa terhadap Kepuasan Pelanggan D\&I Skin Centre Denpasar.UNUD, Vol. 2, No. 8, pp 918-937.

[10] Pongoh, M. E. 2013. Kualitas Pelayanan, Kualitas Produk dan Harga Pengaruhnya terhadap Loyalitas Pelanggan Kartu As Telkomsel di Kota Manado. Jurnal EMBA, Vol. 1, No. 4, pp 86-94.

[11] Aryani, D., \& Rosinta, F. 2010. Pengaruh Kualitas Layanan terhadap Kepuasan Pelanggan dalam Membentuk Loyalitas Pelanggan. Bisnis \& Birokrasi, Jurnal Ilmu Administrasi dan Organisasi, Vol. 17, No. 2, pp 114-126. 
[12] Effendi, U., \& Effendi, M. 2013. Analisis Perencanaan Strategi Peningkatan Kualitas Pelayanan Konsumen dengan Metode Quality Function Deployment (QFD). Jurnal Industrial, Vol. 4, No. 1, pp 41-52.

[13] Kusumo, S., \& Meitha, R. 2013. Perencanaan Strategi Pemasaran Usaha Bengkel Baru. Jurnal Calyptra, Vol. 2, No. 1, p 1-19.

[14] Tjiptono, F dan Chandra, G. 2011. Service, Quality and Satisfaction. Edisi 3. Andi Offset, Yogyakarta.

[15] Tjiptono, Fandy. 2014. Pemasaran Jasa. Andi Offset, Yogyakarta.

[16] Fitzsimmons, J. A. \& Fitzsimmons, M. J. 2011, Service Management Operations, Strategy, Information Technology, Mc Graw - Hill, London.

[17] Saaty, T.L. 2008 'Decision Making with the Analytic Hierarchy Process', Int. J. Services Sciences, Vol. 1, No. 1, pp.83-98. 